Ambiente \& Água - An Interdisciplinary Journal of Applied Science
ISSN 1980-993X - doi:10.4136/1980-993X
www.ambi-agua.net
E-mail: ambi.agua@gmail.com

\title{
Effects of different operating conditions on total nitrogen removal routes and nitrous oxide emissions in a lab-scale activated sludge system
}

\author{
ARTICLES doi:10.4136/ambi-agua.2174
}

Received: 23 Aug. 2017; Accepted: 20 Jan. 2018

\author{
Renato Pereira Ribeiro'; Débora Cynamon Kligerman²; William Zamboni de Mello³ \\ Denise da Piedade Silva ${ }^{4}$; Renatah da Fonseca Correia ${ }^{2}$; Jaime Lopes da Mota Oliveira ${ }^{2 *}$ \\ ${ }^{\mathbf{1}}$ Instituto Federal de Educação, Ciência e Tecnologia do Rio de Janeiro (IFRJ), Nilópolis, RJ, Brasil \\ E-mail: renato.ribeiro@ifrj.edu.br \\ ${ }^{2}$ Fundação Oswaldo Cruz (FIOCRUZ), Rio de Janeiro, RJ, Brasil \\ Departamento de Saneamento e Saúde Ambiental (DSSA). E-mail: deboracyklig@gmail.com, \\ renatah.correia@gmail.com, jaimel@ensp.fiocruz.br \\ ${ }^{3}$ Universidade Federal Fluminense (UFF), Niterói, RJ, Brasil \\ Departamento de Geoquímica (GEO). E-mail: wzamboni@id.uff.br \\ ${ }^{4}$ Universidade Federal do Rio de Janeiro (UFRJ), Rio de Janeiro, RJ, Brasil \\ Centro de Ciências da Saúde (CCS). E-mail: d.silv@yahoo.com.br \\ *Corresponding author
}

\begin{abstract}
This study sought to determine the effects of different operating conditions, such as variable organic loading, different sludge retention times (SRTs) and airflow rates, limited dissolved oxygen (DO) concentrations and ammonium $\left(\mathrm{NH}_{4}{ }^{+}\right)$shock loading on total nitrogen (TN) removal routes and nitrous oxide $\left(\mathrm{N}_{2} \mathrm{O}\right)$ emissions in a lab-scale activated sludge system. Short SRT ( 5 days) combined with very low DO levels $\left(0.5 \mathrm{mg} \mathrm{L}^{-1}\right)$ were responsible for lower TKN oxidation efficiencies and, consequently, negligible $\mathrm{NO}_{2}^{-}$accumulation rates. These results suggest that nitrification efficiency was hampered by the oxidation of organic matter, with a large part of TN removed by sludge waste process. As the SRT increased (from 5 to 10 days) and DO was set to $1.0 \mathrm{mg} \mathrm{L}^{-1}$, TKN oxidation rates and $\mathrm{NO}_{2}{ }^{-}$accumulation reached their maxima, which are thought to be the optimal conditions for both organic matter oxidation and partial nitrification. Under these conditions, gas transfer to the atmosphere became the preferential route for $\mathrm{TN}$ removal instead of incorporation into the sludge waste. However, $\mathrm{N}_{2} \mathrm{O}$ contribution is estimated as less than $5.6 \%$ (with respect to $\mathrm{TN}$ in the influent). Insufficient aeration and stress conditions (such as $\mathrm{NH}_{4}{ }^{+}$shock loading) can cause limited DO conditions and $\mathrm{NO}_{2}{ }^{-}$accumulation, leading to higher amounts of emitted $\mathrm{N}_{2} \mathrm{O}$. Therefore, the adequate control of $\mathrm{DO}$ concentrations is a key factor to avoid $\mathrm{NO}_{2}{ }^{-}$accumulation and consequently high $\mathrm{N}_{2} \mathrm{O}$ emissions.
\end{abstract}

Keywords: activated sludge, dissolved oxygen, nitrite accumulation rate, nitrogen removal routes, nitrous oxide emission. Attribution License, which permits unrestricted use, distribution, and reproduction in any medium, provided the original work is properly cited. 


\section{Efeito das diferentes condições operacionais nas rotas de remoção do nitrogênio total e emissões de óxido nitroso em um sistema de lodos ativados em escala de bancada}

\section{RESUMO}

O principal objetivo deste estudo foi determinar os efeitos das diferentes condições operacionais, tais como carga orgânica variável, diferentes idades do lodo e taxas de aeração, limitação das concentrações de oxigênio dissolvido (OD) e choque de carga de amônio $\left(\mathrm{NH}_{4}^{+}\right)$, nas rotas de remoção do nitrogênio total (NT) e nas emissões de óxido nitroso $\left(\mathrm{N}_{2} \mathrm{O}\right)$ provenientes de um sistema de lodos ativados em escala de bancada. Idades do lodo reduzidas (5 dias) combinadas com baixas concentrações de OD $\left(0,5 \mathrm{mg} \mathrm{L}^{-1}\right)$ foram responsáveis por uma baixa eficiência de oxidação do NT Kjeldahl (NTK) e, consequentemente, negligenciáveis taxas de acúmulo de nitrito $\left(\mathrm{NO}_{2}^{-}\right)$. Esses resultados sugerem uma perda na eficiência da nitrificação completa em razão do maior comprometimento do OD com à oxidação da matéria orgânica, com a maior parcela do $\mathrm{N}$ removida pela incorporação ao lodo excedente. $\mathrm{O}$ aumento da idade do lodo (de 5 para 10 dias) combinada com o aumento da concentração de OD para $1,0 \mathrm{mg} \mathrm{L}{ }^{-1}$, levaram ao alcance das taxas máximas de oxidação do NTK e de acúmulo de $\mathrm{NO}_{2}^{-}$, o que representou uma condição ótima para ambos os processos de oxidação da matéria orgânica e nitrificação incompleta. Sob essas condições, a transferência de gás para a atmosfera tornou-se a rota preferencial de remoção do NT. No entanto, a contribuição do $\mathrm{N}_{2} \mathrm{O}$ foi estimada em até 5,6\% da carga de NT afluente. Condições de stress (choque de carga de $\mathrm{NH}_{4}{ }^{+}$) e aeração insuficiente podem causar períodos de limitação de $\mathrm{OD}$ e acúmulo de $\mathrm{NO}_{2}^{-}$, podendo levar assim à maiores emissões de $\mathrm{N}_{2} \mathrm{O}$. Portanto, o controle adequado das concentrações de $\mathrm{OD}$ é o fator chave para evitar o acúmulo de $\mathrm{NO}_{2}^{-}$e, consequentemente, maiores emissões de $\mathrm{N}_{2} \mathrm{O}$.

Palavras-chave: emissão de óxido nitroso, lodo ativado, oxigênio dissolvido, rotas de remoção de nitrogênio, taxa de acúmulo de nitrito.

\section{INTRODUCTION}

The biological pathway for $\mathrm{N}$ removal in WWTPs is nitrification, followed by denitrification processes (Wrage et al., 2001; Law et al., 2012). The activated sludge process can provide optimal conditions for the conversion of ammonium $\left(\mathrm{NH}_{4}^{+}\right)$to nitrate $\left(\mathrm{NO}_{3}{ }^{-}\right)$ (complete nitrification: $\mathrm{NH}_{4}{ }^{+} \rightarrow \mathrm{NO}_{2}{ }^{-} \rightarrow \mathrm{NO}_{3}{ }^{-}$), especially in tropical regions (Wrage et al., 2001). However, to combine both processes, the design and operation of a traditional WWTP must be altered (i.e. an anoxic zone and internal recirculation systems must be added) to allow for the complete denitrification process, the key process for the effective removal of $\mathrm{N}$ as molecular nitrogen $\left(\mathrm{N}_{2}\right)\left(\mathrm{NO}_{3}{ }^{-} \rightarrow \mathrm{NO}_{2}{ }^{-} \rightarrow \mathrm{NO} \rightarrow \mathrm{N}_{2} \mathrm{O} \rightarrow \mathrm{N}_{2}\right)$ (Wrage et al., 2001). Another route for $\mathrm{N}$ removal is by the sludge waste process (Lee et al., 2008; Bernat et al., 2011). Recently, several studies have addressed $\mathrm{N}$ removal processes under many controlled operating conditions, such as hydraulic retention time (HRT), sludge retention time (SRT), dissolved oxygen (DO) concentrations and organic loading rates, among others (Bernat et al., 2011; Rassol et al., 2014; Xiang et al., 2014; Lu et al., 2015). However, only some of these studies calculated the total N (TN) balance (Lee et al., 2008; Bernat et al., 2011).

WWTPs with biological N removal (BNR) are an effective way to decrease the discharge of oxidized $\mathrm{N}$ forms $\left(\right.$ as $\mathrm{NO}_{3}{ }^{-}$) into water bodies and thus prevent eutrophication. On the other hand, nitrous oxide $\left(\mathrm{N}_{2} \mathrm{O}\right)$ emissions from WWTPs are an issue of international concern and should also be taken into account (Keller and Hartley, 2003; IPCC, 2006). Currently, wastewater treatment systems are thought to contribute with about $10 \%$ of total anthropogenic 
$\mathrm{N}_{2} \mathrm{O}$ emissions, when including both manure and sewage treatments (Desloover et al., 2012). $\mathrm{N}_{2} \mathrm{O}$ is one of the most important substances from an environmental point of view, since it is linked to global warming and climate change. It is a greenhouse gas with a global warming potential 310 times that of carbon dioxide $\left(\mathrm{CO}_{2}\right)$, contributing approximately $7 \%$ to overall greenhouse gases (IPCC, 2013). In addition, $\mathrm{N}_{2} \mathrm{O}$ is indirectly responsible for the depletion of stratospheric ozone $\left(\mathrm{O}_{3}\right)$ by its reaction with excited oxygen atoms and nitric oxide (NO) production: $\mathrm{N}_{2} \mathrm{O}+\mathrm{O}\left({ }^{1} \mathrm{D}\right) \rightarrow 2 \mathrm{NO}$ and $\mathrm{NO}+\mathrm{O}_{3} \rightarrow \mathrm{NO}_{2}+\mathrm{O}_{2}$ (Crutzen, 1979; Ravishankara et al., 2009). Ravishankara et al. (2009) believe that $\mathrm{N}_{2} \mathrm{O}$ will become the major dominant ozonedepleting substance before the end of this century.

During nitrification and denitrification processes, respectively, $\mathrm{N}_{2} \mathrm{O}$ is formed as a by-product of $\mathrm{NH}_{4}{ }^{+}$oxidation to nitrite $\left(\mathrm{NO}_{2}{ }^{-}\right)$and as an intermediate of the reduction of oxidized $\mathrm{N}$ forms to $\mathrm{N}_{2}$ (Wrage et al., 2001). Generally, there is no single $\mathrm{N}_{2} \mathrm{O}$ emission mechanism from WWTPs and the pathways related to its production are dependent on the WWTP design and closely related to operating conditions (Ahn et al., 2011; Hu et al., 2013). Nitrification is reported as the main source of $\mathrm{N}_{2} \mathrm{O}$ emission under DO limitations and, consequently, high $\mathrm{NO}_{2}{ }^{-}$concentrations. However, the denitrification process can contribute significantly to higher $\mathrm{N}_{2} \mathrm{O}$ emissions under an insufficient organic carbon source $(\mathrm{C} / \mathrm{N}$ ratio) with high $\mathrm{NO}_{2}{ }^{-}$concentrations (Kampschreur et al., 2009; Law et al., 2012). Thus, the operating conditions that lead to the accumulation of $\mathrm{NO}_{2}^{-}$concentrations are subject to high $\mathrm{N}_{2} \mathrm{O}$ emissions. Therefore, further studies are required to elucidate the importance of controlling operational conditions in order to reduce $\mathrm{NO}_{2}{ }^{-}$concentrations and thus mitigate $\mathrm{N}_{2} \mathrm{O}$ emissions (Desloover et al., 2012).

In this context, this study sought to determine the effects of different operating conditions, such as variable organic loading, different SRTs and airflow rates, limited DO concentrations and $\mathrm{NH}_{4}{ }^{+}$shock loading, on TN removal routes and $\mathrm{N}_{2} \mathrm{O}$ emissions in a lab-scale activated sludge system.

\section{MATERIALS AND METHODS}

\subsection{Lab-scale system and regular operating condition}

A continuous lab-scale reactor (total volume $=20 \mathrm{~L}$ ) consisting of four adjacent and interconnected chambers ( $\mathrm{V}=5 \mathrm{~L}$ ) was monitored over 212 days (Figure 1). For the first 135 days, the lab-scale system functioned with some small variations of load (denoted as regular operating condition) to promote the acclimatization of the biomass to the synthetic wastewater. These some small variations occurred as a function of the storage conditions of the synthetic sewage used to supply the reactor. The first chamber $\left(\mathrm{C} 1\right.$; average $\left.\mathrm{DO}<0.1 \mathrm{mg} \mathrm{L}^{-1}\right)$ was used as a biological selector (with pre-denitrification) and a mixing zone of the synthetic wastewater and biological sludge that returns from the settler $(\mathrm{V}=2 \mathrm{~L})$. The other three chambers $(\mathrm{V}=15 \mathrm{~L})$ were aerated so as to maintain DO concentrations near $2.0 \mathrm{mg} \mathrm{L}^{-1}$. During this period, HRT and SRT were maintained at 12 hours and 10 days, respectively. The continuous flow rate of synthetic wastewater was $1.7 \mathrm{~L} \mathrm{~h}^{-1}$. Sludge recycling was performed by a peristaltic pump, pumping the biological sludge from the settler to the anoxic chamber $(\mathrm{C} 1)$, at a flow of $1.7 \mathrm{~L} \mathrm{~h}^{-1}$. Internal recirculation was present, in order to allow for the return of $\mathrm{NO}_{2}{ }^{-}$and $\mathrm{NO}_{3}{ }^{-}$ to the reactor, at a flow rate of $3.7 \mathrm{~L} \mathrm{~h}^{-1}$. 


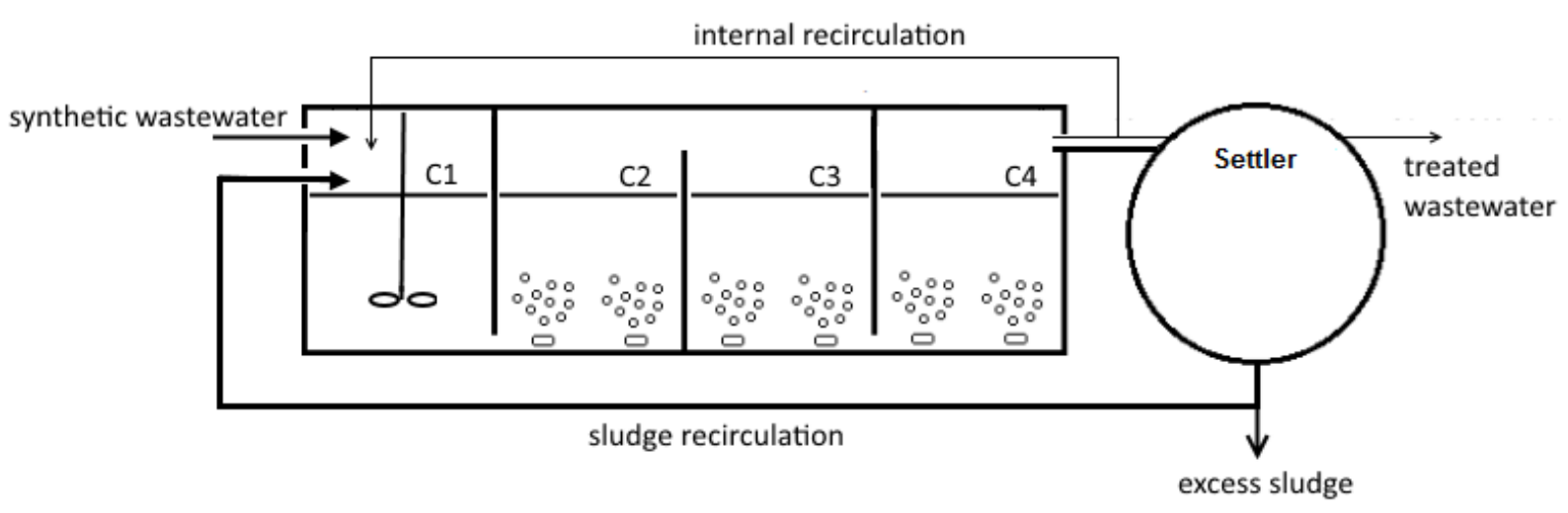

Figure 1. Schematic design of the lab-scale activated sludge system.

\subsection{Operating conditions to determine the distribution of the routes of $\mathrm{TN}$ removal}

To determine the relative distribution of the TN removal routes (sludge and atmosphere) under different operating conditions, the reactor was submitted to a two-phased experimental condition (Phases 1 and 2), between the $135^{\text {th }}$ and the $212^{\text {nd }}$ monitoring days, with different SRTs, limited DO concentrations (in C2-C4) and variable organic loading. Phase 1 was carried out between the $135^{\text {th }}$ and the $169^{\text {th }}$ day, under a SRT of 5 days and DO concentration of $0.5 \mathrm{mg} \mathrm{L}^{-1}$, and Phase 2, between the $169^{\text {th }}$ and the $212^{\text {nd }}$ day, under a SRT of 10 days and DO concentration of $1.0 \mathrm{mg} \mathrm{L}^{-1}$. The SRT was maintained for 5 or 10 days by controlling sludge wastage and monitoring the concentration of volatile suspended solids (VSS) in the reactor and the sludge recirculation line. In both phases, the HRT was maintained at 12 hours. The first 19 days of Phase 1 were considered an adaptation period (from the $135^{\text {th }}$ to the $154^{\text {th }}$ day), and the same was set for the first 21 days of Phase 2 (from the $170^{\text {th }}$ to the $191^{\text {st }}$ day). The process was performed at room temperature, at approximately $25^{\circ} \mathrm{C}$.

\subsection{Operating conditions to determine the magnitude of $\mathrm{N}_{2} \mathrm{O}$ emissions}

After conducting the experiment described previously (item 2.2.), the system was discontinued due to problems in its three peristaltic pumps used for the input of synthetic wastewater, sludge recirculation and internal recirculation. With the acquisition of new pumps (Masterflex), the continuous lab-scale system was restarted for a new 80-day experiment. The system was operated under the same operating condition as Phase 2 (SRT of 10 days and DO concentrations near $\left.1.0 \mathrm{mg} \mathrm{L}^{-1}\right)$. The purpose was to achieve the accumulation of $\mathrm{NO}_{2}^{-}$ concentrations, and, after the $72^{\text {nd }}$ monitoring day, to determine the magnitude of $\mathrm{N}_{2} \mathrm{O}$ emissions (and the $\mathrm{N}_{2} \mathrm{O} / \mathrm{N}_{\text {atmosphere }}$ ratio) under different operating conditions, such as variable organic loading and different air flow rates applied to promote different DO levels (in $\mathrm{C} 2-\mathrm{C} 4$ ) (and $\mathrm{NO}_{2}{ }^{-}$concentrations) in the reactor. Four experimental conditions (EC) were performed varying the air flow rates, as follows, in chronological order: $200 \mathrm{~mL} \mathrm{~min}^{-1}$ (EC 1: $74^{\text {th }}$ day), $50 \mathrm{~mL} \min ^{-1}$ (EC 2: $76^{\text {th }}$ day), $300 \mathrm{~mL} \mathrm{~min}^{-1}$ (EC 3: $78^{\text {th }}$ day) and $400 \mathrm{~mL} \mathrm{~min} \mathrm{~m}^{-1}$ (EC 4: $80^{\text {th }}$ day). The stabilization period for each EC was of 24 hours.

\subsection{Biological sludge and wastewater composition}

The biological sludge used in this work was collected from a WWTP and the reactor was fed with the synthetic wastewater. The synthetic wastewater was prepared mixing casein peptone $\left(320 \mathrm{mg} \mathrm{L}^{-1}\right)$, meat extract $\left(220 \mathrm{mg} \mathrm{L}^{-1}\right)$, urea $\left(60 \mathrm{mg} \mathrm{L}^{-1}\right)$, potassium monohydrogen phosphate $\left(56 \mathrm{mg} \mathrm{L}^{-1}\right)$, sodium chloride $\left(14 \mathrm{mg} \mathrm{L}^{-1}\right)$, calcium chloride dihydrate $\left(8 \mathrm{mg} \mathrm{L}^{-1}\right)$ and magnesium sulfate heptahydrate $\left(4 \mathrm{mg} \mathrm{L}^{-1}\right)$ (Holler and Trösch, 2001). The $\mathrm{pH}$ of the synthetic wastewater ranged between 7 and 8. Variations in chemical oxygen demand (COD) and TN concentrations were obtained by increasing or decreasing the amount of substances, like casein peptone, meat extract and urea, in the synthetic wastewater. 


\subsection{Sampling and analytical procedures}

Table 1 displays the sampling strategy used for the different operating conditions of the continuous lab-scale system. Liquid samples of synthetic and treated wastewaters were regularly collected to determine COD, TKN and TN concentrations. Liquid and gas samples from the four chambers were collected during the experimental operating conditions to determine the relative distribution of TN removal routes (Phases 1 and 2) and the magnitude of $\mathrm{N}_{2} \mathrm{O}$ emissions (ECs 1-4). Liquid samples were filtered through $0.22 \mu \mathrm{m}$ cellulose acetate membrane filters for the determination of dissolved inorganic nitrogen (DIN $=\mathrm{NH}_{4}{ }^{+}, \mathrm{NO}_{2}{ }^{-}$and $\mathrm{NO}_{3}{ }^{-}$) forms. In addition, VSS and TN sampling and analyses were carried out in the reactor and sludge recycler. The DO concentrations in the reactor were directly measured by a multiparameter Hanna portable meter (Model HI9828).

Gas samples were collected every 15 minutes, totaling 180 minutes per monitoring day (between the $74^{\text {th }}$ and the $80^{\text {th }}$ days), covering the four chambers of the lab-scale reactor for the determination of the $\mathrm{N}_{2} \mathrm{O}$ emissions. A modified upturned funnel was used as the gas sampling technique (on a lab-scale). This same technique has been applied by our group in full-scale WWTP studies (Mello et al., 2013; Ribeiro et al., 2015; Brotto et al., 2015). The $\mathrm{N}_{2} \mathrm{O}$ emission rate (ER) for the reactor was calculated by multiplying the $\Delta \mathrm{N}_{2} \mathrm{O}$ concentration, which is the difference between the upturned funnel headspace and the atmospheric $\mathrm{N}_{2} \mathrm{O}$ concentrations, by the emerging airflow rate $\left(Q_{\text {air }}\right.$ ), as displayed in Equation (1). The latter was measured at the surface of the reactor using the upturned funnel and a digital rotameter, and the result was scaled up for the entire reactor.

$\mathrm{N}_{2} \mathrm{O}$ ER $\left(\mathrm{mg} \mathrm{N} \mathrm{h}^{-1}\right)=\Delta \mathrm{N}_{2} \mathrm{O}$ concentration $\times \mathrm{Q}_{\text {air }} \times\left(\mathrm{A}_{\text {reactor }} / \mathrm{A}_{\text {upturned funnel }}\right)$

Table 1. Sampling strategy for the different operating conditions.

\begin{tabular}{ccccc}
\hline \multirow{2}{*}{ Samples } & \multicolumn{2}{c}{ Items 2.1 and 2.2 } & \multicolumn{2}{c}{ Item $2.3^{\text {nay }}$} \\
\cline { 2 - 5 } & $\left(0-135^{\text {th }} \text { day }\right)^{\mathrm{a}}$ & $\left(135-212^{\text {nd }} \text { day }\right)^{\mathrm{b}}$ & $\left(0-72^{\text {nd }} \text { day }\right)^{\mathrm{c}}$ & $\left(74-80^{\text {th }} \text { day }\right)^{\mathrm{d}}$ \\
\hline Synthetic wastewater & COD and TN & COD, TKN and TN & TKN and TN & TKN and TN \\
Lab-scale reactor & DO and VSS & DIN, DO and VSS & DIN, DO and VSS & DIN, N2O, DO and VSS \\
Sludge excess & VSS & TN and VSS & VSS & TN and VSS \\
Treated wastewater & COD and TN & COD, TKN and TN & TKN and TN & TKN and TN \\
\hline
\end{tabular}

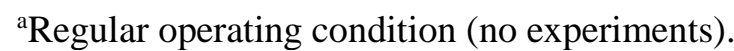

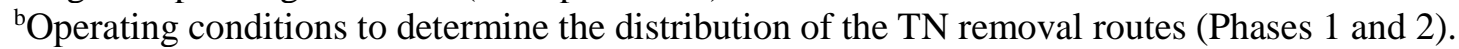

'Same operating condition as Phase 2.

dOperating conditions to determine the magnitude of $\mathrm{N}_{2} \mathrm{O}$ emissions (EC 1-4).

In the laboratory, $\mathrm{N}_{2} \mathrm{O}$ determinations were performed on a Shimadzu gas chromatograph (Model GC-17) equipped with an electron capture detector with ${ }^{63} \mathrm{Ni}$ source. The limits of detection and quantification were of 30 and $300 \mathrm{ppb}$, respectively. All analytical procedures followed APHA et al. (2012) protocols. COD, TKN and TN were determined using the closed reflux colorimetric, block digestion and direct persulfate digestion methods, respectively. VSS concentrations were determined by the gravimetric method. $\mathrm{NH}_{4}{ }^{+}$concentrations were measured using an ammonia ion-selective electrode method coupled to an Orion $\mathrm{pH}$-meter (Model Star 5). $\mathrm{NO}_{2}{ }^{-}$and $\mathrm{NO}_{3}{ }^{-}$concentrations were determined by ion chromatography with chemical suppression of eluent conductivity on a Methrohm ion chromatograph (Model 790 Personal). The limits of quantification were of $0.03 \mathrm{mg} \mathrm{L}^{-1}$ for $\mathrm{NH}_{4}^{+}, 0.1 \mathrm{mg} \mathrm{L}^{-1}$ for $\mathrm{NO}_{2}^{-}$and $\mathrm{NO}_{3}{ }^{-}$, and $10 \mathrm{mg} \mathrm{N} \mathrm{L}^{-1}$ for $\mathrm{TN}$. The analytical precision of the analyses performed in triplicate was within $\pm 5 \%$. 


\section{RESULTS AND DISCUSSION}

\subsection{Regular operating condition}

During the first 135 monitoring days, influent COD and TN concentrations (and volumetric COD and TN loads) varied from 447 to $1054 \mathrm{mg} \mathrm{L}^{-1}\left(0.5\right.$ and $\left.1.3 \mathrm{~kg} \mathrm{~m}^{-3} \mathrm{day}^{-1}\right)$ and from 59 to $130 \mathrm{mg} \mathrm{L}^{-1}\left(0.1\right.$ and $0.2 \mathrm{~kg} \mathrm{~m}^{-3}$ day $\left.^{-1}\right)$, respectively. The average COD and TN removal efficiencies ( \pm standard deviation) were $92 \%( \pm 1.4 \%)$ and $57 \%( \pm 6.6 \%)$, respectively. Using a lab-scale sequential batch reactor (SBR) system with fixed low volumetric COD load $(0.4 \mathrm{~kg}$ $\mathrm{m}^{-3}$ day $^{-1}$ ), Lee et al. (2008) found COD and TN removal efficiencies of 92\% and 65\%, respectively. Similar values were reported by Vaiopoulou et al. (2007) for COD (74-97\%), although their TN removal efficiency was somewhat higher, around $70 \%$. They operated a differential lab-scale activated sludge system with a denitrification cascade and worked with a wide range of influent volumetric COD loads applied to the system $\left(0.3\right.$ to $\left.2.0 \mathrm{~kg} \mathrm{~m}^{-3} \mathrm{day}^{-1}\right)$. Vaiopoulou et al. (2007) reported that the higher influent flow rate distribution to the reactor zones (denitrification cascade) explained the higher TN removal rates, in contrast to our study, that operated only with pre-denitrification.

The variability of the organic loading did not have any effect on COD removal efficiency, although lower TN removal efficiencies were related to lower influent TN concentrations. Between the $9^{\text {th }}$ and the $21^{\text {st }}$ monitoring day, influent TN concentrations dropped to about $30 \%$, resulting in a decrease in TN removal efficiency, from 63 to $48 \%$ (Figure 2A). The same happened between the $55^{\text {th }}$ and the $76^{\text {th }}$ monitoring day, when the influent TN concentration dropped about $40 \%$ and TN removal efficiency decreased from 67 to $41 \%$. These results indicate that significant decreases in influent $\mathrm{TN}$ concentrations result in decreasing $\mathrm{TN}$ removal efficiencies, given that TN concentrations and its removal efficiencies are positively correlated $(\mathrm{r}=0.68 ; \mathrm{n}=10 ; \mathrm{p}<0.01)$ (Figure 2B). Liu et al. (2012) observed losses in TN removal efficiency when applying lower volumetric $\mathrm{NH}_{4}{ }^{+}$loads from a SBR using a completely autotrophic nitrogen-removal via nitrite $(\mathrm{CANON})$ process. On the other hand, Zhang et al. (2014) demonstrated that maximal TN removal efficiency (90\%) was obtained in a lab-scale sequencing batch biofilm reactor (SBBR) after 132 days of operation, where the volumetric TN load was gradually increased from 0.08 to $0.6 \mathrm{~kg} \mathrm{~m}^{-3} \mathrm{day}^{-1}$.

\subsection{The relative distribution of $T N$ removal routes}

The fate of the removed TN was determined based on mass flow rates of the influent wastewater, liquid effluent and sludge waste. TN removal via mass transfer to the atmosphere was calculated by the difference between the influent TN load and TN removal via liquid effluent and sludge waste, as displayed in Equation 2.

TNatmosphere $=$ TNinfluent $-($ TNliquid effluent + TNsludge waste $)$

Figure 3 shows the relative distribution of TN loss (and removal) calculated for the three different outlet routes from the 154th to the 169th day (Phase 1) and from the 191st to the 212nd day (Phase 2). The average TN removal efficiency of the system in the Phase 1 was of approximately $50 \%$, of which about $40 \%$ was incorporated by the sludge waste and $10 \%$ released to the atmosphere. This result can be explained by the short SRT (5 days) and very low DO levels ( $\mathrm{DO}=0.5 \mathrm{mg} \mathrm{L}-1)$. Short SRT can lead to an increased net sludge production rate and, consequently, higher TN removal by biomass production. During this phase, the net sludge production rate increased from 9 to $13 \mathrm{~g}$ VSS day-1 under high volumetric COD (on average: $1 \mathrm{~kg} \mathrm{~m}-3$ day-1) and TN (on average: $0.1 \mathrm{~kg} \mathrm{~m}-3$ day-1) loading conditions. Bernat et al. (2011) reported that a high biomass production was responsible for $16-26 \%$ of the TN removed in a SBR at limited DO concentrations $(<0.7 \mathrm{mg} \mathrm{L}-1)$ and that these values were the result of a low 
specific biomass decay rate. In addition, Lee et al. (2008) reported that 50\% of the influent TN in a SBR was removed by the sludge waste process.
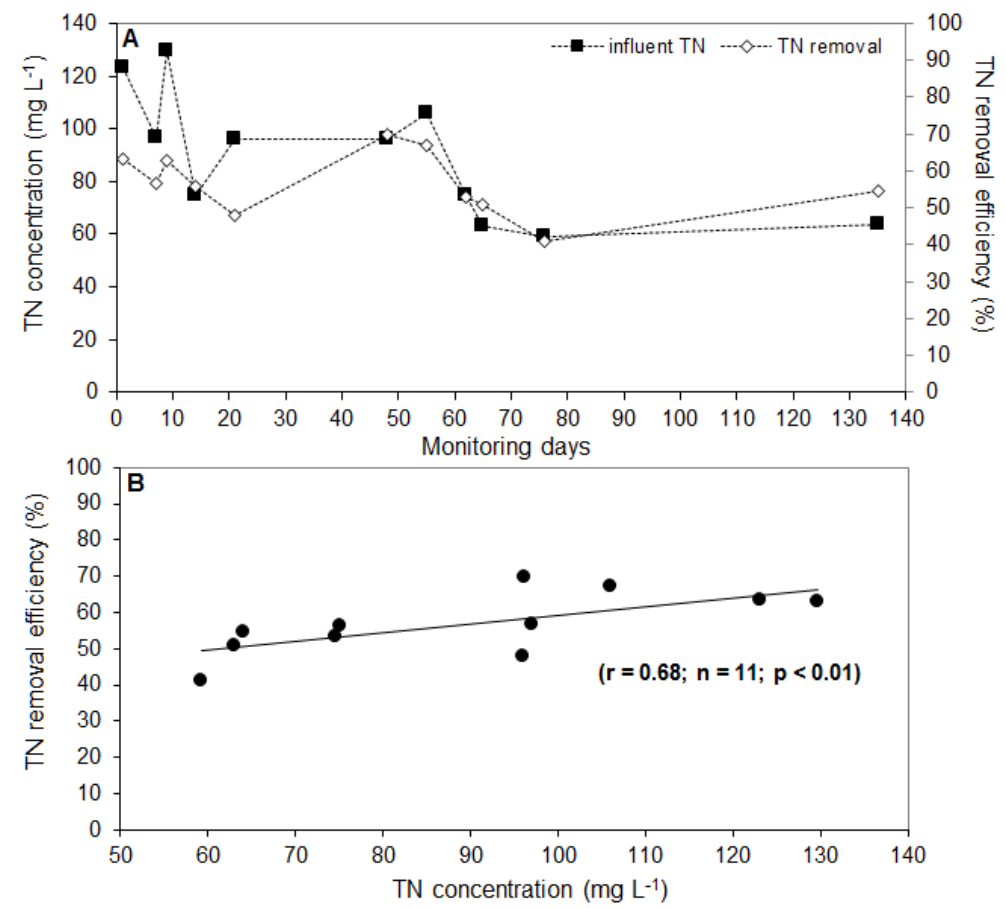

Figure 2. (A) Influent $\mathrm{TN}$ concentrations $\left(\mathrm{mg} \mathrm{L}^{-1}\right)$ and $\mathrm{TN}$ removal efficiencies $(\%)$ of the lab-scale activated sludge system. (B) Correlation between TN removal efficiencies and influent TN concentrations.

During Phase 2, the average TN removal efficiency was approximately 60\% (Figure 3). Throughout this phase, TN removal via mass transfer to the sludge waste decreased from 40 to 15\%. Concomitantly, the fraction transferred to the atmosphere increased from 10 to $50 \%$. This can be explained by the increasing SRT (from 5 to 10 days) and DO levels (from 0.5 to $1.0 \mathrm{mg} \mathrm{L}^{-1}$ ). Longer SRT can lead to decreases in the sludge mass by endogenous metabolism and, consequently, lower TN removal by biomass production. During this period, the net sludge production rate decreased from 13 to $6 \mathrm{~g} \mathrm{VSS} \mathrm{day}^{-1}$ even under the same volumetric COD and TN loadings applied to Phase 1.

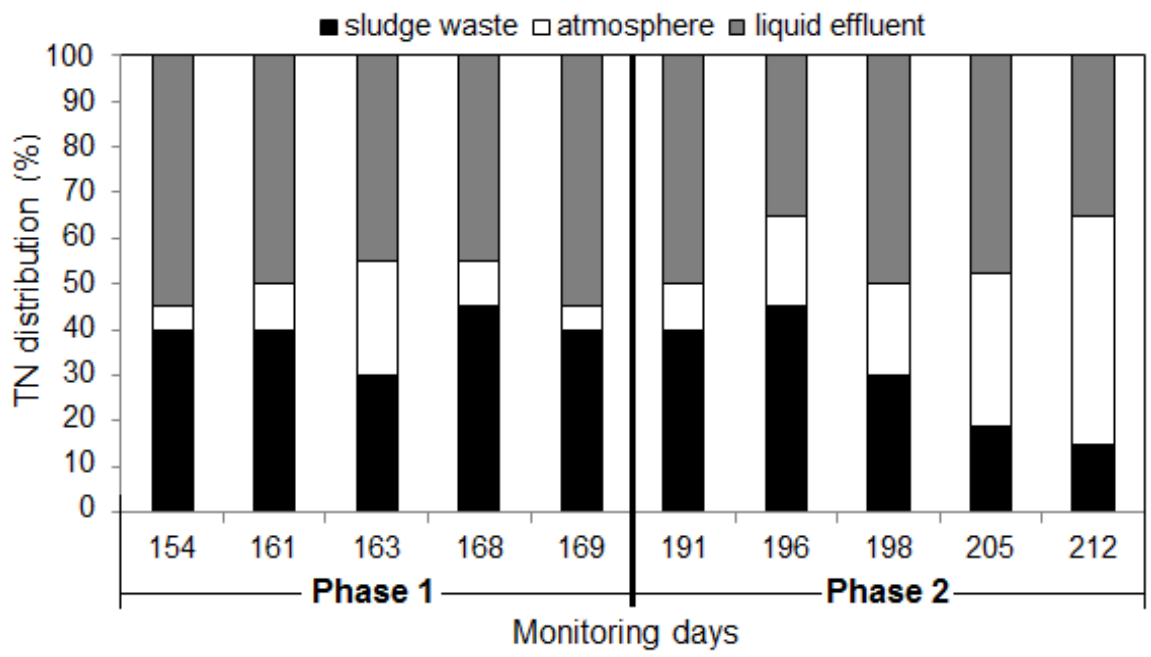

Figure 3. TN distribution (\%) (regarding TN in the influent) in the different system lines (sludge waste, atmosphere and liquid effluent). 
Figure 4 displays the effects of DO limitation on DIN concentrations during Phases 1 and 2. $\mathrm{NH}_{4}{ }^{+}$was the predominant form of $\mathrm{N}$ in the reactor during Phase 1 (Figure 4A), due to lower TKN oxidation efficiencies (40-60\%) (Figure 4B). Consequently, $\mathrm{NO}_{2}^{-}$accumulation rates (NAR) were below $15 \%$ when the airflow rate was set to maintain DO levels close to $0.5 \mathrm{mg} \mathrm{L}^{-1}$, with a SRT of 5 days. For the calculation of NAR the equation cited by Wei et al. (2014) was used. These results suggest loss of nitrification efficiency with no accumulation of $\mathrm{NO}_{2}^{-}$, since DO was restricted by organic matter oxidation. Therefore, the operational condition applied in Phase 1 was characterized by loss of nitrification activity, which explains the highest TN removal efficiencies by the sludge waste (Figure 3).

During Phase 2, $\mathrm{NH}_{4}^{+}$concentrations dropped below $10 \mathrm{mg} \mathrm{L}^{-1}$, with $\mathrm{NO}_{2}{ }^{-}$as the major form of DIN after the $200^{\text {th }}$ monitoring day (Figure 4A). The NAR then began to prevail and increased up to $80 \%$, with TKN oxidation reaching efficiencies above $80 \%$ (Figure 4B). At DO set near $1.0 \mathrm{mg} \mathrm{L}^{-1}$ with a SRT of 10 days, this phase showed optimal conditions for both organic matter oxidation and partial nitrification. Ruiz et al. (2003) reported that around 65\% of the influent $\mathrm{TN}$ load was converted into $\mathrm{NO}_{2}^{-}$in a lab-scale activated sludge reactor, operating at DO around $0.7 \mathrm{mg} \mathrm{L}-1$. These authors reported that when DO was below $0.5 \mathrm{mg} \mathrm{L}^{-1}, \mathrm{NH}_{4}^{+}$accumulated in the system. The effect of increasing DO concentrations (from 0.5 to $1.0 \mathrm{mg} \mathrm{L}^{-1}$ ) seems to explain the accumulation of $\mathrm{NO}_{2}{ }^{-}$, since Pollice et al. (2002) reported that $\mathrm{NO}_{2}{ }^{-}$accumulation took place regardless of the SRT during oxygen-limiting conditions (DO $<2 \mathrm{mg} \mathrm{L}^{-1}$ ) in a lab-scale activated sludge reactor. Therefore, in conditions that favor partial nitrification, it is probable that the priority route of nitrogen removal will be through the atmospheric path (Figure 3).

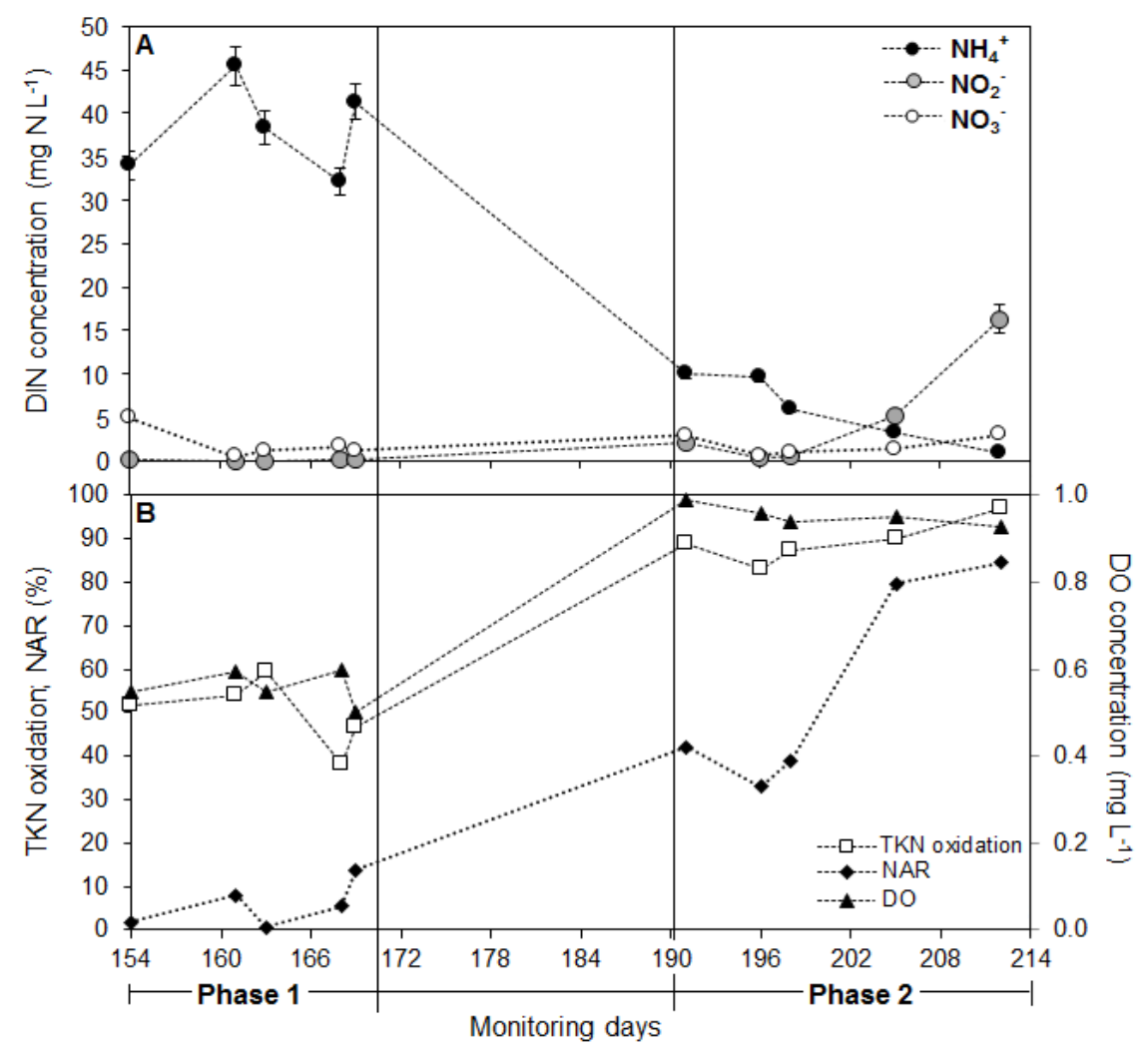

Figure 4. (A) Average $\mathrm{DIN}\left(\mathrm{NH}_{4}^{+}, \mathrm{NO}_{2}^{-}\right.$and $\left.\mathrm{NO}_{3}^{-}\right)$ concentrations ( $\mathrm{mg} \mathrm{N} \mathrm{L}^{-1}$ ) in the three aerobic chambers, (B) TKN oxidation (\%), $\mathrm{NO}_{2}{ }^{-}$accumulation rates (NAR) (\%) and DO concentrations $\left(\mathrm{mg} \mathrm{L}^{-1}\right)$ during the $154^{\text {th }}$ to $212^{\text {th }}$ monitoring days in the lab-scale reactor. 


\subsection{Under the same operating condition as Phase 2}

In order to achieve $\mathrm{NO}_{2}{ }^{-}$accumulation, the system was restarted and operated under the same conditions as Phase 2. During the first 37 days, $\mathrm{NH}_{4}{ }^{+}$concentrations ranged from 5 to $10 \mathrm{mg} \mathrm{L}^{-1}$ in the reactor (Figure 5A) with high TKN oxidation efficiencies (80-95\%) (Figure 5B). These values are similar to those found in Phase 2, displayed in Figure 4. On the other hand, $\mathrm{NO}_{3}{ }^{-}$was the predominant form of $\mathrm{N}$ in the reactor, with low $\mathrm{NO}_{2}{ }^{-}$concentrations $\left(<0.9 \mathrm{mg} \mathrm{N} \mathrm{L}^{-1}\right.$ ) (Figure 5A). These results suggest favorable conditions for the completion of the nitrification process (and negligible NAR), since DO concentrations were above $1.0 \mathrm{mg} \mathrm{L}^{-1}$ (ranging from 0.9 to $1.8 \mathrm{mg} \mathrm{L}^{-1}$ ) (Figure 5B). However, when DO concentrations dropped to $\leq 1 \mathrm{mg} \mathrm{L}^{-1}$ (ranging from 0.7 to $1.1 \mathrm{mg} \mathrm{L}^{-1}$ ), $\mathrm{NO}_{2}^{-}$became the main form of oxidized $\mathrm{N}$ in the reactor, without loss of TKN oxidation efficiency. Interestingly, $\mathrm{NH}_{4}{ }^{+}$concentrations were remained constant throughout the last monitoring days, especially between the $37^{\text {th }}$ and the $72^{\text {nd }}$ day. In addition, NAR increased from 0 to $90 \%$ and $\mathrm{NO}_{3}{ }^{-}$concentrations were low $\left(<1 \mathrm{mg} \mathrm{N} \mathrm{L}^{-1}\right)$. These results indicate the transition from complete to partial nitrification, and, thus, the greater fraction of $\mathrm{N}$ was transferred to the atmosphere, as observed previously in Phase 2 (Figure 3).

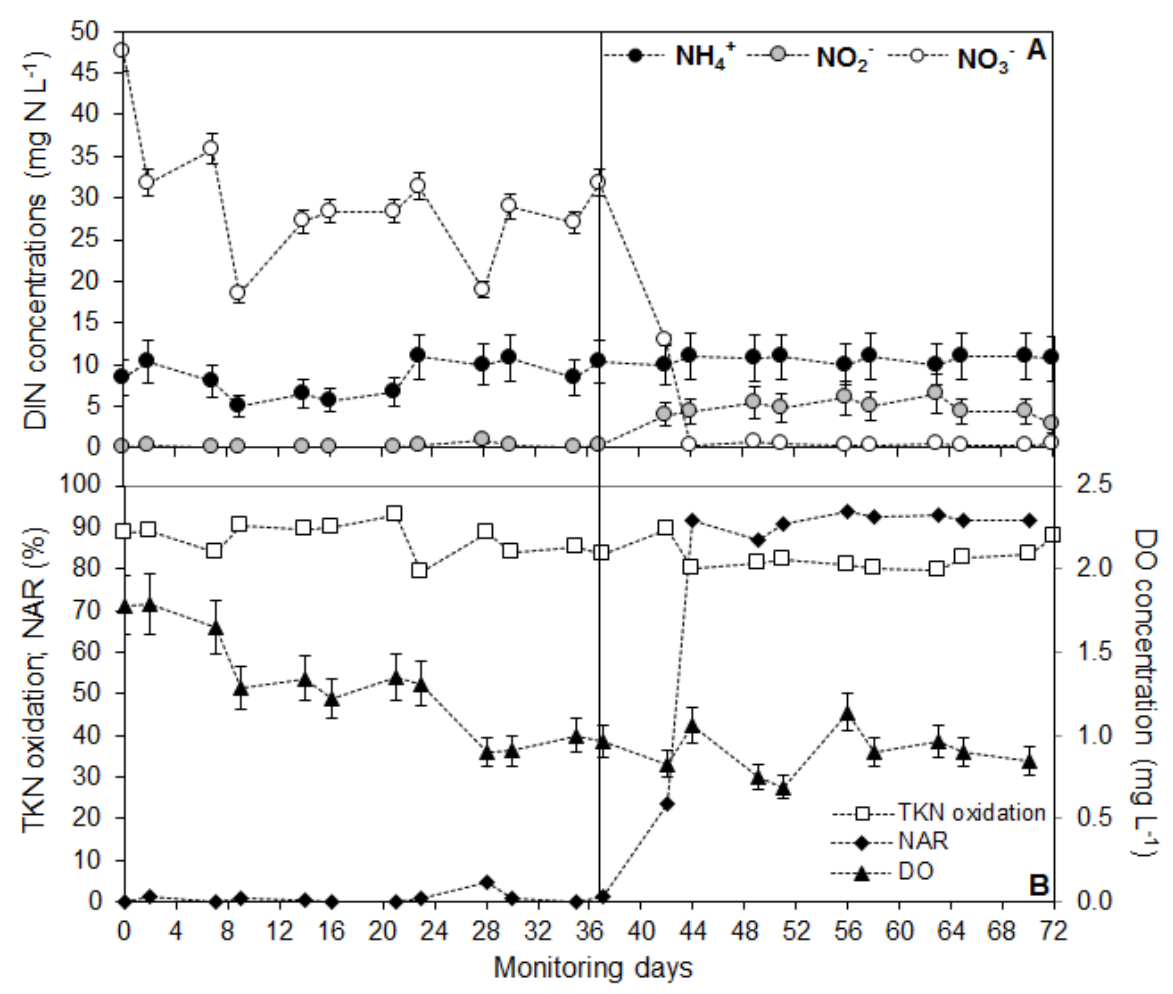

Figure 5. (A) Average $\mathrm{DIN}\left(\mathrm{NH}_{4}^{+}, \mathrm{NO}_{2}^{-}\right.$and $\left.\mathrm{NO}_{3}^{-}\right)$ concentrations in the three aerobic chambers; (B) TKN oxidation (\%), $\mathrm{NO}_{2}^{-}$accumulation rate (NAR) (\%) and DO concentrations $\left(\mathrm{mg} \mathrm{L}^{-1}\right)$ during 72 monitoring days.

\subsection{Extent of $\mathrm{N}_{2} \mathrm{O}$ emissions}

Figure 6 displays the average DIN concentrations in the three aerobic chambers of the labscale reactor (Figure 6A), as well as TKN oxidation and NAR values (Figure 6B) under the different experimental conditions (EC 1-4). In addition, Figure 6C displays the $\mathrm{N}_{2} \mathrm{O}$ emission variations and DO concentrations in the four experimental conditions. In EC 1 $\left(Q_{\text {air }}=200 \mathrm{~mL} \mathrm{~min}^{-1}\right), \mathrm{NH}_{4}{ }^{+}$was the predominant form of $\mathrm{N}$ in the reactor, followed by $\mathrm{NO}_{2}{ }^{-}$ and $\mathrm{NO}_{3}{ }^{-}$, respectively, $64 \%\left(11 \mathrm{mg} \mathrm{N} \mathrm{L}^{-1}\right), 30 \%\left(5.2 \mathrm{mg} \mathrm{N} \mathrm{L}^{-1}\right)$ and $6 \%\left(1.1 \mathrm{mg} \mathrm{N} \mathrm{L}^{-1}\right)$ (Figure $6 \mathrm{~A}$ ). In addition, TKN oxidation and NAR were $76 \%$ and $84 \%$, respectively (Figure 6B). More 
of the influent $\mathrm{TN}$ was converted to $\mathrm{NO}_{2}^{-}(11 \%)$ than to $\mathrm{NO}_{3}^{-}(2 \%)$. In this experimental condition, DO concentrations varied from 0.9 to $1.1 \mathrm{mg} \mathrm{L}^{-1}$ (Figure 6C). These results are similar to those observed by Ruiz et al. (2003), that reported $\mathrm{NO}_{2}{ }^{-}$accumulation with DO concentrations close to $0.7 \mathrm{mg} \mathrm{L}^{-1}$. Significant variations in $\mathrm{N}_{2} \mathrm{O}$ emissions were observed within the range of 1.4 to $4.1 \mathrm{mg} \mathrm{N} \mathrm{h}^{-1}$, representing on average $2.6 \mathrm{mg} \mathrm{N} \mathrm{h}^{-1}$ and $5.4 \%$ when normalized by influent TN load.

Similar NH4 $4^{+}$concentrations $\left(9.6 \mathrm{mg} \mathrm{N} \mathrm{L}^{-1}\right)$ and TKN oxidation rates $(73 \%)$ were observed in EC 2 (Qair $=50 \mathrm{~mL} \mathrm{~min}^{-1}$ ) operating at an airflow rate four-fold lower than EC 1 (Figures $6 \mathrm{~A}$ and $6 \mathrm{~B})$. However, $\mathrm{NO}_{3}^{-}\left(0.6 \mathrm{mg} \mathrm{N} \mathrm{L}^{-1}\right)$ and, especially, $\mathrm{NO}_{2}^{-}\left(0.1 \mathrm{mg} \mathrm{N} \mathrm{L}^{-1}\right)$ concentrations were low, and, consequently, with NAR of $14 \%$. In this condition, the DO concentrations were much lower (0.1-0.3 $\left.\mathrm{mg} \mathrm{L}^{-1}\right)$ due to the lower airflow rate applied to the system (Figure 6C). Therefore, under anoxic conditions, both $\mathrm{NO}_{2}{ }^{-}$and $\mathrm{NO}_{3}{ }^{-}$were probably reduced by complete denitrifying activity, without significant $\mathrm{N}_{2} \mathrm{O}$ emissions $\left(<0.5 \mathrm{mg} \mathrm{N} \mathrm{h}^{-1}\right)$, which represented, on average, $0.1 \mathrm{mg} \mathrm{N} \mathrm{h}^{-1}$ and $0.3 \%$ of the influent $\mathrm{TN}$ load. In a lab-scale system with activated sludge, Wunderlin et al. (2012) reported that $\mathrm{N}_{2} \mathrm{O}$ emissions under anoxic conditions are likely to be of minor importance when operated without significant NO2- accumulation $\left(<2 \mathrm{mg} \mathrm{N} \mathrm{L}^{-1}\right)$.

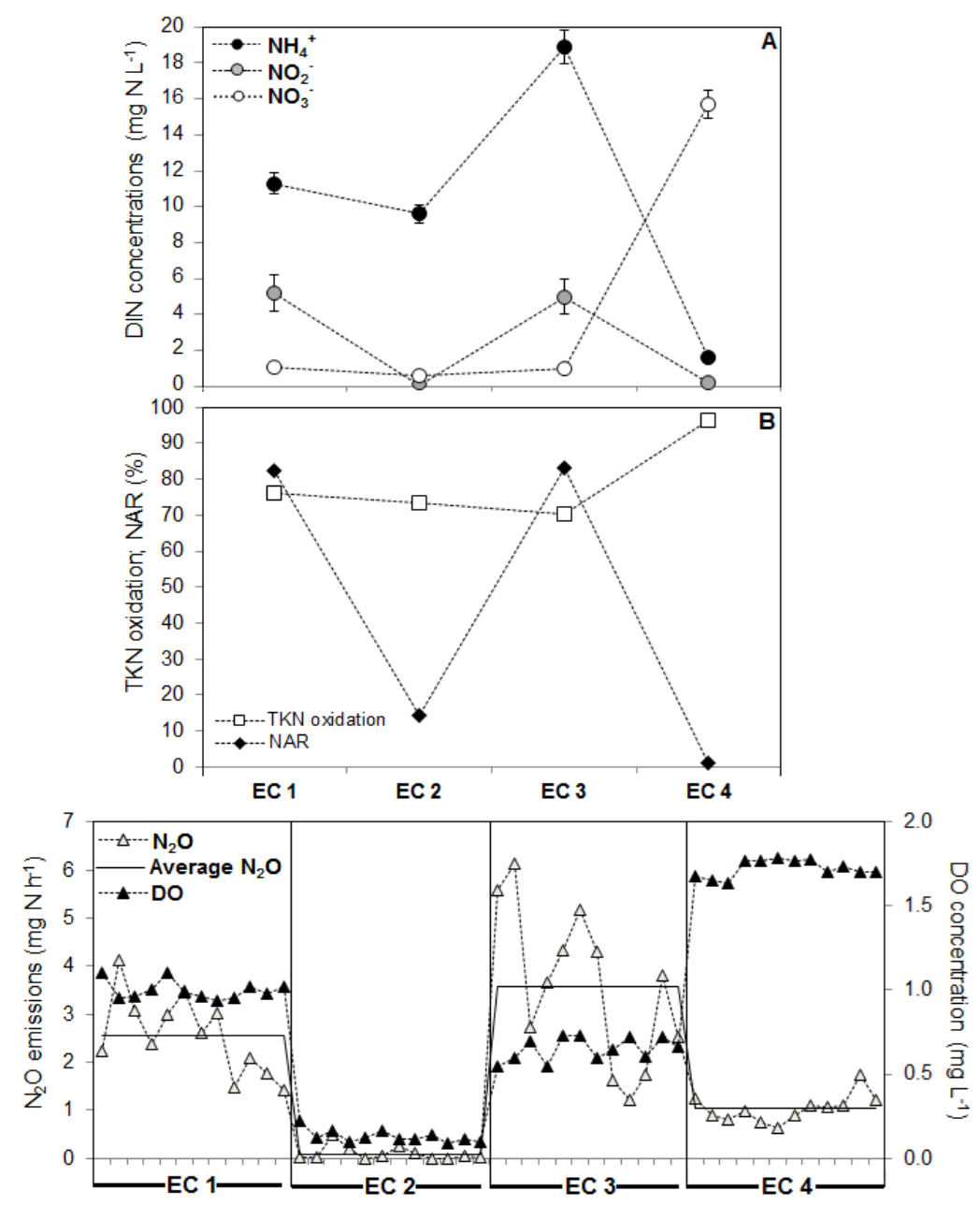

Figure 6. (A) Average DIN $\left(\mathrm{NH}_{4}^{+}, \mathrm{NO}_{2}^{-}\right.$and $\left.\mathrm{NO}_{3}^{-}\right)$ concentrations $\left(\mathrm{mg} \mathrm{N} \mathrm{L}^{-1}\right)$ in the three aerobic chambers, (B) TKN oxidation $(\%)$ and $\mathrm{NO}_{2}^{-}$accumulation rate (NAR) (\%) and (C) $\mathrm{N}_{2} \mathrm{O}$ emissions $\left(\mathrm{mg} \mathrm{N} \mathrm{h}^{-1}\right)$ and $\mathrm{DO}$ concentrations $\left(\mathrm{mg} \mathrm{L}^{-1}\right)$ in the lab-scale reactor for each of the four experimental conditions. 
In EC $3\left(\mathrm{Q}_{\text {air }}=300 \mathrm{~mL} \mathrm{~min}^{-1}\right)$, as in $\mathrm{EC} 1$, more of the influent $\mathrm{TN}$ was converted to $\mathrm{NO}_{2}^{-}$ (8\%) than to $\mathrm{NO}_{3}{ }^{-}(2 \%)$. Moreover, similar TKN oxidation rates $(70 \%)$ and $\mathrm{NO}_{2}{ }^{-}$accumulation $(83 \%)$ were observed (Figures 6A and 6B). However, unlike EC 1, the average values of $\mathrm{NH}_{4}{ }^{+}$ concentrations for the three aerobic chambers in EC 3 were much higher and linked to higher influent $\mathrm{NH}_{4}{ }^{+}$concentrations (shock loading). Consequently, higher variations in $\mathrm{N}_{2} \mathrm{O}$ emissions were observed, within the range of 1.2 to $6.1 \mathrm{mg} \mathrm{N} \mathrm{h}^{-1}$ (Figure 6C). Nevertheless, this represents an average of $3.6 \mathrm{mg} \mathrm{N} \mathrm{h}^{-1}$ and $5.6 \%$ of the influent $\mathrm{TN}$ load, very similar to what was found in $\mathrm{EC} 1$. The $\mathrm{NH}_{4}{ }^{+}$shock loading was responsible for reducing and maintaining DO concentrations close to $0.7 \mathrm{mg} \mathrm{L}^{-1}$ (Figure 6C) even under higher air flow rates when compared to EC 1 and EC 2. It could be argued that sudden changes, such as $\mathrm{NH}_{4}{ }^{+}$shock loading, can lead to $\mathrm{NO}_{2}{ }^{-}$accumulation (partial nitrification) and higher $\mathrm{N}_{2} \mathrm{O}$ emissions, as reported by other authors (Foley et al., 2010; Rodriguez-Caballero et al., 2013; Toor et al., 2015). Ahn et al (2010) suggested that the trigger for $\mathrm{N}_{2} \mathrm{O}$ emissions from aerobic zones are simultaneous high $\mathrm{NH}_{4}{ }^{+}$and $\mathrm{NO}_{2}{ }^{-}$concentrations, based on studies performed in full-scale BNR and non-BNR processes.

The highest airflow rate to the system was applied in EC $4\left(\mathrm{Q}_{\text {air }}=400 \mathrm{~mL} \mathrm{~min}^{-1}\right)$, and a different behavior was observed in relation to the other $3 \mathrm{ECs}$, since around $35 \%$ of the influent TN was converted into $\mathrm{NO}_{3}{ }^{-}$(the predominant form of DIN in the reactor). In addition, $\mathrm{NH}_{4}{ }^{+}$ (1.6 $\left.\mathrm{mg} \mathrm{N} \mathrm{L}^{-1}\right)$ and $\mathrm{NO}_{2}^{-}\left(0.2 \mathrm{mg} \mathrm{N} \mathrm{L}^{-1}\right)$ concentrations were low, with $96 \%$ TKN oxidation and negligible NAR (Figures 6A and 6B). In this condition, DO concentrations were above $1.5 \mathrm{mg}$ $\mathrm{L}^{-1}$ and $\mathrm{N}_{2} \mathrm{O}$ emissions varied from 0.6 to $1.8 \mathrm{mg} \mathrm{N} \mathrm{h}^{-1}$ (on average $1.0 \mathrm{mg} \mathrm{N} \mathrm{h}^{-1}$ and $2.3 \%$ of the influent TN load) (Figure 6C). This low $\mathrm{N}_{2} \mathrm{O}$ emission can be attributed to complete nitrification. It could be argued that this experimental condition favors greater DO availability (> $1.5 \mathrm{mg} \mathrm{L}^{-1}$ ) for organic matter oxidation and complete nitrification and, consequently, low $\mathrm{N}_{2} \mathrm{O}$ emissions. In studies performed both in the laboratory and in full-scale processing, Rodriguez-Caballero et al. (2013) and Song et al. (2014), respectively, reported lower $\mathrm{N}_{2} \mathrm{O}$ emissions from complete nitrification compared to partial nitrification (with $\mathrm{NO}_{2}{ }^{-}$ accumulation). Therefore, to reduce $\mathrm{N}_{2} \mathrm{O}$ emissions, activated sludge systems should be operated at low $\mathrm{NH}_{4}{ }^{+}$(without shock loading) and $\mathrm{NO}_{2}{ }^{-}$concentrations (without build-up) (Ahn et al., 2010; Foley et al., 2010; Wunderlin et al. 2012; Aboobakar et al., 2013). This condition can be achieved through longer SRT, equalization of organic loading and optimal control of airflow rates, depending on the DO concentrations in the reactor.

Figure 7 displays the relative distribution of TN loss (and removal) through three different system routes, (1) sludge waste, (2) atmosphere (via $\mathrm{N}_{2}$ and $\mathrm{N}_{2} \mathrm{O}$ separately) and (3) remaining in the liquid effluent for each of the four experimental conditions. The TN removal efficiencies of the system were high and ranged from 61 to $71 \%$. A lower fraction of TN was removed by the sludge waste process and was similar in the four evaluated conditions (7-9\%). Most of the TN was removed via gas transfer to the atmosphere (53-64\%), with the highest efficiency associated to $\mathrm{EC} \mathrm{2.} \mathrm{Of} \mathrm{the} \mathrm{amount} \mathrm{of} \mathrm{TN} \mathrm{transferred} \mathrm{to} \mathrm{the} \mathrm{atmosphere,} \mathrm{a} \mathrm{significant}$ $\mathrm{N}_{2} \mathrm{O} / \mathrm{N}_{\text {atmosphere }}$ ratio was attributed to EC $1(11 \%)$ and EC $3(10 \%)$. On the other hand, the $\mathrm{N}_{2} \mathrm{O} / \mathrm{N}_{\text {atmosphere }}$ ratio decreased from 10 to $5 \%$ due to transition from EC 3 (partial nitrification) to EC 4 (complete nitrification), as described previously and reported by other studies (Rodriguez-Caballero et al., 2013; Song et al., 2014). Therefore, the adequate control of DO concentrations is a key factor, in order to avoid the accumulation of $\mathrm{NO}_{2}{ }^{-}$and, therefore, achieve lower $\mathrm{N}_{2} \mathrm{O}$ emissions. 


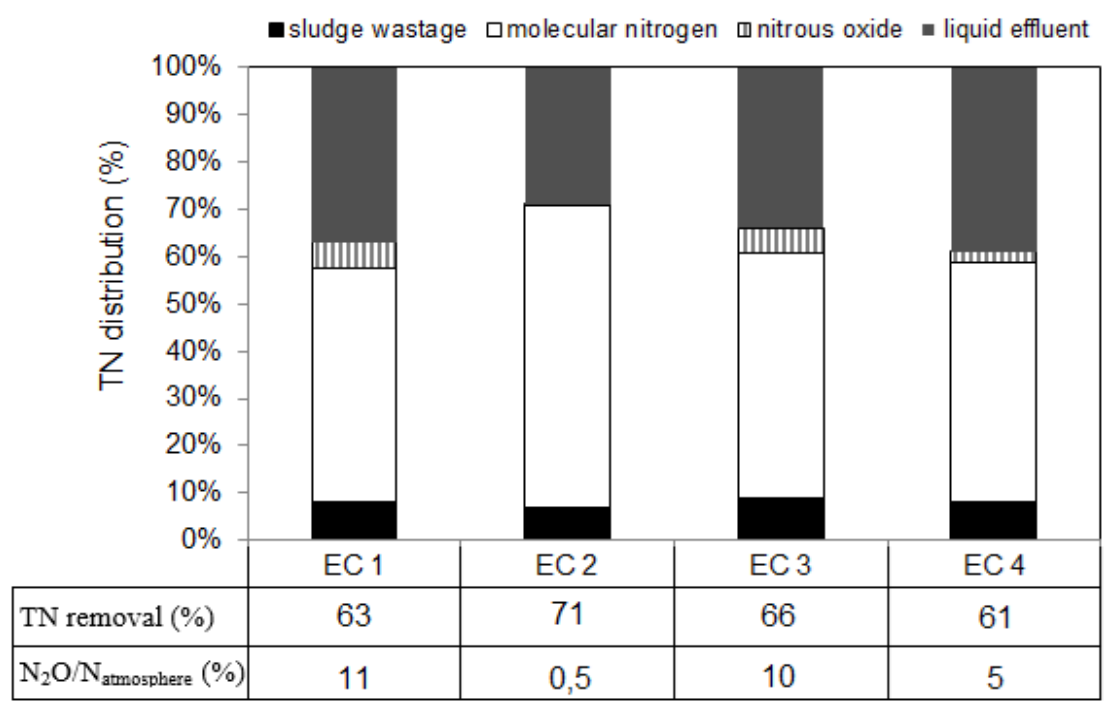

Figure 7. TN distribution (\%) (regarding TN in the influent) through three different system routes: sludge waste, atmosphere (via $\mathrm{N}_{2}$ and $\mathrm{N}_{2} \mathrm{O}$ separately) and liquid effluent for each of the four experimental conditions. In addition, $\mathrm{TN}$ removal $(\%)$ and $\mathrm{N}_{2} \mathrm{O} / \mathrm{N}_{\text {atmosphere }}$ ratio (\%) are also displayed.

\section{CONCLUSION}

The effects of different operating conditions, such as variable organic loading, different SRTs and airflow rates, limited DO concentrations and $\mathrm{NH}_{4}{ }^{+}$shock loading on $\mathrm{TN}$ removal routes and $\mathrm{N}_{2} \mathrm{O}$ emissions were studied in a lab-scale activated sludge system and the major conclusions are:

- The variable organic loading did not interfere with COD removal efficiency under the applied operating conditions. However, lower TN removal efficiencies were related to lower TN loads.

- Short SRT (5 days) resulted in a large part of TN removal in sludge waste. As the SRT increased from 5 to 10 days, TN removal decreased in the sludge waste and increased via the atmospheric route.

- Low DO levels $\left(0.5 \mathrm{mg} \mathrm{L}^{-1}\right)$ were responsible for lower TKN oxidation efficiencies, suggesting that nitrification efficiency was hampered by the oxidation of organic matter. For DO set to $1 \mathrm{mg} \mathrm{L}^{-1}$, TKN oxidation rates and $\mathrm{NO}_{2}{ }^{-}$accumulation reached their maxima, the best condition for both organic matter oxidation and partial nitrification.

- Part of the $\mathrm{N}$ transferred to the atmosphere is attributed to $\mathrm{N}_{2} \mathrm{O}$ emissions (reaching a maximum $\mathrm{N}_{2} \mathrm{O} / \mathrm{N}_{\text {atmosphere }}$ ratio of $10 \%$ ), which varied from 0.3 to $5.6 \%$ of the influent TN load.

- The presence of combined remnant $\mathrm{NH}_{4}{ }^{+}$and high $\mathrm{NO}_{2}{ }^{-}$concentrations due to partial nitrification strongly triggered $\mathrm{N}_{2} \mathrm{O}$ emissions.

- Insufficient aeration and stress conditions (such as $\mathrm{NH}_{4}{ }^{+}$shock loading) can cause limited DO conditions, $\mathrm{NO}_{2}{ }^{-}$accumulation and, consequently, higher $\mathrm{N}_{2} \mathrm{O}$ emissions.

- The adequate control of DO concentrations is a key factor to avoid $\mathrm{NO}_{2}{ }^{-}$accumulation and, consequently, high $\mathrm{N}_{2} \mathrm{O}$ emissions. 


\section{ACKNOWLEDGMENTS}

This work was supported by Coordenação de Aperfeiçoamento de Pessoal de Nível Superior (Capes).

\section{REFERENCES}

ABOOBAKAR, A.; CARTMELL, E.; STEPHENSON, T.; JONES, M.; VALE, P.; DOTRO, G. Nitrous oxide emissions and dissolved oxygen profiling in a full-scale nitrifying activated sludge treatment plant. Water Research, v. 47, p. 524-534, 2013. https://doi.org/10.1016/j.watres.2012.10.004

AHN, J.O.; KIM, S.; PARK, H.; RAHM, B.; PAGILLA, K.; CHANDRAN, K. N $\mathrm{N}_{2} \mathrm{O}$ emissions from activated sludge processes, 2008-2009: results of a national monitoring survey in the United States. Environmental Science and Technology, v. 44, p. 4505-4511, 2010. http://dx.doi.org/10.1021/es903845y

AHN, J. H.; KWAN, T.; CHANDRAN, K. Comparison of partial and full nitrification processes applied for treating high-strength nitrogen wastewaters: microbial ecology through nitrous oxide production. Environmental Science and Technology, v. 45, n. 7, p. 27342740, 2011. http://dx.doi.org/10.1021/es103534g

AMERICAN PUBLIC HEALTH ASSOCIATION/AMERICAN WATER WORKS ASSOCIATION/WATER ENVIRONMENT FEDERATION. Standard Methods for the Examination of Water and Wastewater. 22 ${ }^{\text {th }}$ ed. Washington DC, 2012.

BERNAT, K.; KULIKOWSKA, D.; ZIELINSKA, M.; CYDZIK-KWIATKOWSKA, A.; WOJNOWSKA-BARYLA, I. Nitrogen removal from wastewater with a low COD/N ratio at a low oxygen concentration. Bioresource and Technology, v. 102, n. 7, p. 49134916, 2011. https://doi.org/10.1016/j.biortech.2010.12.116

BROTTO, A. C.; KLIGERMAN, D. C.; ANDRADE, S. A.; RIBEIRO, R. P.; OLIVEIRA, J. L. M.; CHANDRAN, K.; DE MELLO, W. Z. Factors controlling nitrous oxide emissions from a full-scale activated sludge system in the tropics. Environmental Science and Pollution Research International, v. 22, p. 11840-11849, 2015. https://doi.org/10.1007/s11356-015-4467-x

CRUTZEN, P. J. The role of NO and NO2 in the chemistry of the troposphere and stratosphere. Annual Review of Earth and Planetary Sciences, v. 7, p. 443-472, 1979. https://doi.org/10.1146/annurev.ea.07.050179.002303

DESLOOVER, J.; VLAEMINCK, S. E.; CLAUWAERT, P.; VERSTRAETE, W.; BOON, N. Strategies to mitigate $\mathrm{N} 2 \mathrm{O}$ emissions from biological nitrogen removal systems. Current Opinion in Chemical Biology, v. 23, p. 474-482, 2012. https://doi.org/10.1016/j.copbio.2011.12.030

FOLEY, J.; DE HAAS, D.; YUAN, Z.; LANT, P. Nitrous oxide generation in full-scale biological nutrient removal wastewater treatment plants. Water Research, v. 44, p. 831844, 2010. https://doi.org/10.1016/j.watres.2009.10.033

HOLLER, S; TRÖSCH, W. Treatment of urban wastewater in a membrane bioreactor at high organic loading rates. Journal of Biotechnology, v. 92, n. 2, p. 95-101, 2001. https://doi.org/10.1016/S0168-1656(01)00351-0 
HU, Z.; ZHANG, J.; XIE, H.; LIANG, S.; LI, S. J. Minimization of nitrous oxide emission from anoxic-oxic biological nitrogen removal process: effect of influent $\mathrm{COD} / \mathrm{NH}_{4}{ }^{+}$ratio and feeding strategy. Journal of Bioscience and Bioengineering, v. 115, p. 272-278, 2013. https://doi.org/10.1016/j.jbiosc.2012.09.016

INTERGOVERNMENTAL PANEL ON CLIMATE CHANGE - IPCC. IPCC Guidelines for National Greenhouse Gas Inventories, v. 5. Kanagawa, 2006.

INTERGOVERNMENTAL PANEL ON CLIMATE CHANGE - IPCC. Climate Change: the physical science basis. Cambridge: Cambridge University Press, 2013.

KAMPSCHREUR, M. J.; TEMMINK, H.; KLEEREBEZEM, R.; JETTEN, M. S. M.; VAN LOOSDRECHT, M. C. M. Nitrous oxide emission during wastewater treatment. Water Research, v. 43, p. 4093-4103, 2009. https://doi.org/10.1016/j.watres.2009.03.001

KELLER, J.; HARTLEY, K. Greenhouse gas production in wastewater treatment: Process selection is the major factor. Water Science and Technology, v. 47, n. 12, p. 43-48, 2003.

LAW, Y.; YE, L.; PAN, Y.; YUAN, Z. Nitrous oxide emissions from wastewater treatment processes. Philosophical Transactions of the Royal Society B, v. 367, n. 1593, p. 12651277, 2012. http://dx.doi.org/10.1098/rstb.2011.0317

LEE, J. K.; CHOI, C. K.; LEE, K. H.; YIM, S. B. Mass balance of nitrogen, and estimates of $\mathrm{COD}$, nitrogen and phosphorus used in microbial synthesis as a function of sludge retention time in a sequencing batch reactor system. Bioresource and Technology, v. 99, n. 16, p. 7788-7796, 2008. https://doi.org/10.1016/j.biortech.2008.01.057

LIU, T.; LI, D.; ZENG, H.; LI, X.; ZENG, T.; CHANG, X.; CAI, Y.; ZHANG, J. Biodiversity and quantification of functional bacteria in completely autotrophic nitrogen-removal over nitrite (CANON) process. Bioresource and Technology, v. 118, p. 399-406, 2012. https://doi.org/10.1016/j.biortech.2012.05.036

LU, Q.; WU, H.; LI, H.; YANG, D. Enhanced biological nutrient removal in modified carbon source division anaerobic-anoxic-oxic process with return activated sludge preconcentration. Chinese Journal of Chemical Engineering, v. 23, n. 6, p. 1027-1034, 2015. https://doi.org/10.1016/j.cjche.2014.11.013

MELLO, W. Z. de; RIBEIRO, R. P.; BROTTO, A. C.; KLIGERMAN, D. C.; PICCOLI, A. S.; OLIVEIRA, J. L. M. Nitrous oxide emission from an intermittent aeration activated sludge system of an urban wastewater treatment plant. Química Nova, v. 36, p. 16-20, 2013. http://dx.doi.org/10.1590/S0100-40422013000100004

POLLICE, A.; TANDOI, V.; LESTINGI, C. Influence of aeration and sludge retention time on ammonium oxidation to nitrite and nitrate. Water Research, v. 36, n. 10, p. 2541-2546, 2002. https://doi.org/10.1016/S0043-1354(01)00468-7

RASOOL, K.; AHN, D. H.; LEE, D. S. Simultaneous organic carbon and nitrogen removal in an anoxic-oxic activated sludge system under various operating conditions. Bioresource Technology, v. 162, p. 373-378, 2014. https://doi.org/10.1016/j.biortech.2014.03.108

RAVISHANKARA, A. R.; DANIEL, J. S.; PORTMAN, R. W. Nitrous oxide $\left(\mathrm{N}_{2} \mathrm{O}\right)$ : the dominant ozone depleting substance emitted in the $21^{\text {st }}$ century. Science, v. 326, p. 123 125, 2009. http://dx.doi.org/10.1126/science.1176985 
RIBEIRO, R. P.; ALVIM, R. B.; ANDRADE, S. A.; KLIGERMAN, D. C.; DE ALMEIDA, P. A.; OLIVEIRA, J. L. M.; et al. Controlling factors of nitrous oxide emissions from a conventional activated sludge wastewater treatment plant. Engevista, v. 17, n. 3, p. 375384, 2015. https://doi.org/10.22409/engevista.v17i3.698

RODRIGUEZ-CABALLERO, A.; RIBERA, A.; BALCÁZAR, J. L.; PIJUAN, M. Nitritation versus full nitrification of ammonium-rich wastewater: Comparison in terms of nitrous and nitric oxides emissions. Bioresource and Technology, v. 139, p. 195-202, 2013. https://doi.org/10.1016/j.biortech.2013.04.021

RUIZ, G.; JEISON, D.; CHAMY, R. Nitrification with high nitrite accumulation for the treatment of wastewater with high ammonia concentration. Water Research, v. 37, n. 6, p. 1371-1377, 2003. https://doi.org/10.1016/S0043-1354(02)00475-X

SONG, K.; SUENAGA, T.; HAMAMOTO, A.; SATOU, K.; RIYA, S.; HOSOMI, M. et al. Abundance, transcription levels and phylogeny of bacteria capable of nitrous oxide reduction in a municipal wastewater treatment plant. Journal of Bioscience and $\begin{array}{lllllll}\text { Bioengineering, } & \text { v. } & 118, & \text { n. } & 3, & \text { p. }\end{array}$ https://doi.org/10.1016/j.jbiosc.2014.02.028

TOOR, U. A.; HAN, D. W.; KIM, D. J. Effect of organics on nitrous oxide emission during wastewater nitrification with enriched nitrifiers. International Biodeterioration and Biodegradation, v. 102, p. 94-99, 2015. https://doi.org/10.1016/j.ibiod.2015.03.011

VAIOPOULOU, E.; MELIDIS, P.; AIVASIDIS, A. An activated sludge treatment plant for integrated removal of carbon, nitrogen and phosphorus. Desalination, v. 211, n. 1-3, p. 192-199, 2007. https://doi.org/10.1016/j.desal.2006.02.092

XIANG, H.; LI, X.; HOJAE, S.; SHANFA, Z.; YANG, D. Biological nutrient removal in a fullscale anoxic/anaerobic/aerobic/pre-anoxic-MBR plant for low $\mathrm{C} / \mathrm{N}$ ratio municipal wastewater treatment. Chinese Journal of Chemical Engineering, v. 22, n. 4, p. 447 454, 2014. https://doi.org/10.1016/S1004-9541(14)60064-1

WEI, D.; SHI, L.; ZHANG, G.; WANG, Y.; SHI, S.; WEI, Q. et al. Comparison of nitrous oxide emissions in partial nitrifying and full nitrifying granular sludge reactors treating ammonium-rich wastewater. Bioresource Technology, v. 171, p. 487-490, 2014. https://doi.org/10.1016/j.biortech.2014.08.071

WRAGE, N.; VELTHOF, G. L.; VAN BEUSICHEM, M. L.; OENEMA, O. Role of nitrifier denitrification in the production of nitrous oxide. Soil Biology and Biochemistry, v. 33, n. 12-13, p. 1723-1732, 2001. https://doi.org/10.1016/S0038-0717(01)00096-7

WUNDERLIN, P.; MOHN, J.; JOSS, A.; EMMENEGGER, L.; SIEGRIST, H. Mechanisms of $\mathrm{N}_{2} \mathrm{O}$ production in biological wastewater treatment under nitrifying and denitrifying conditions. Water Research, v. 46, n. 4, p. 1027-1037, 2012. https://doi.org/10.1016/j.watres.2011.11.080

ZHANG, J.; ZHOU, J.; HAN, Y.; ZHANG, X. Start-up and bacterial communities of singlestage nitrogen removal using anammox and partial nitritation (SNAP) for treatment of high strength ammonia wastewater. Bioresource and Technology, v. 169, p. 652-657, 2014. https://doi.org/10.1016/j.biortech.2014.07.042 